\title{
Ocorrência de oídio em Mentha x villosa
}

\author{
Hugo José Tozze Júnior ${ }^{1}$, Daniel Garcia Júnior ${ }^{1}$, Nelson Sidnei Massola Júnior ${ }^{1}$
}

'Departamento de Entomologia, Fitopatologia e Zoologia Agrícola, Escola Superior de Agricultura "Luiz de Queiroz”, Av. Pádua Dias, 11, 13418-900, Piracicaba, SP.

Autor para correspondência: Nelson S. Massola Júnior.<nmassola@esalq.usp.br>

Data de chegada: 16/11/2004. Aceito para publicação em: 06/10/2005.

Dentre as espécies do gênero Mentha cultivadas no Brasil, M. $x$ villosa (M. crispa) destaca-se pelo uso culinário e na forma de chás, com efeito medicinal. Esta é comumente comercializada in natura e empregada popularmente como espasmolítica, antivomitiva, carmiativa, estomáquica e anti-helmíntica. Recentemente, tem sido utilizada no tratamento contra ameba, giárdia e tricomonas, com elevado percentual de cura.

Em Piracicaba, SP, foi observado oídio em plantas de $M . x$ villosa num cultivo doméstico dessa erva. Nas plantas afetadas, a doença se concentrava nas folhas baixeiras, causando amarelecimento e grande desfolha. Nas folhas, a colonização pelo fungo se mostrava epifítica e anfígena, porém, exibia forte tendência hipófila.

Amostras foliares foram coletadas das plantas doentes e submetidas ao exame microscópico, por meio de microscopia de luz e microscopia eletrônica de varredura. Em ambas as análises, caracterizaram-se morfologicamente os conídios, conidióforos e apressórios.

Para a microscopia de luz, lâminas semi-permanentes foram preparadas, tendo como meio de montagem o lactofenol. Cinqüenta conídios e trinta células basais dos conidióforos, aleatoriamente escolhidos, tiveram o comprimento e a largura mensurados, usando-se aumento de 400x. Verificou-se também a possível presença de corpos de fibrosina nos conídios, por meio do preparo de lâminas usando uma solução de $\mathrm{KOH}$ como meio de montagem.

Para os exames em microscopia eletrônica de varredura, segmentos de folhas colonizados pelo fungo foram fixados, desidratados e metalizados com vapor de ouro. Posteriormente, foram observados em microscópio eletrônico de varredura Zeiss DSM 940-A.

Testes de inoculação em plantas sadias foram realizados, em condições controladas. A partir de plantas doentes, coletaram-se esporos, que foram transferidos, com auxílio de um pincel de cerdas macias, para ambas as superfícies de folhas de plantas sadias, mantidas em vasos. Após a manifestação dos sintomas e sinais nas plantas inoculadas, amostras foliares foram retiradas e submetidas aos mesmos procedimentos de microscopia já descritos.

O exame microscópico do material fúngico sobre as plantas doentes revelou a presença de conídios doliformes, medindo 23,5-32,5 x 15,0-20,2 $\mu \mathrm{m}$, com média de 26,8-17,4 $\mu \mathrm{m}$. Os conidióforos mostraram-se simples, cilíndricos, com célula basal medindo 58,3-80 x 11,9-14,4 $\mu$ m, seguidas por 2 ou 3 células. O contorno das cadeias de conídios imaturos foi classificado como sinuado. Os apressórios apresentaram-se indistintos, caracterizados apenas por leve dilatação da hifa (Figura 1). Não foram observados corpos de fibrosina nos conídios. Estruturas da fase sexuada também não foram observadas.

Duas semanas após a inoculação, as plantas inoculadas apresentavam sintomas e sinais bastante evidentes (Figura 1). Assim como nas plantas observadas no campo, a colonização se mostrou anfígena, porém, com forte tendência hipófila. O patógeno presente nas plantas inoculadas apresentou as mesmas características morfológicas apresentadas pelo fungo observado em plantas de Mentha no campo.

As características morfológicas do patógeno, descritas neste trabalho, assemelham-se às observadas para as fases anamórficas do gênero Erysiphe, mesmo gênero já relatado em outras espécies de Mentha. Uma vez que a espécie $M$. x villosa apresenta pouca expressão econômica, testes de patogenicidade em $M$. arvensis necessitariam ser realizados para verificar se $M$. $x$ villosa se comporta como hospedeiro alternativo para o oídio de $M$. $a r$ vensis, esta última com maior expressão econômica no Brasil. Este é o primeiro relato de Erysiphe causando oídio na espécie M. x villosa.

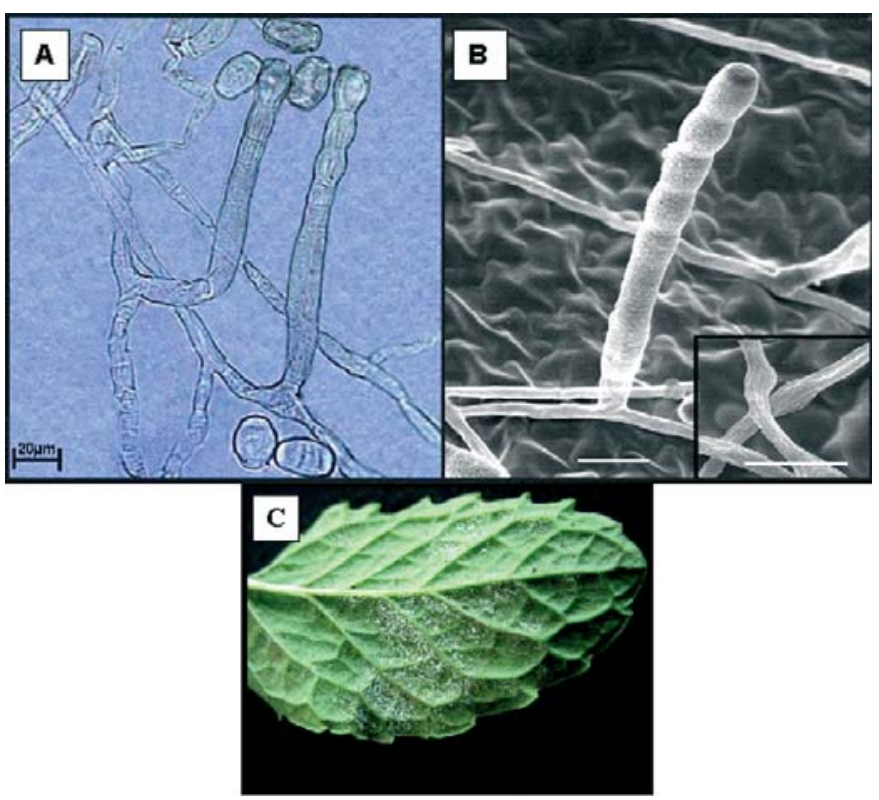

Figura 1. Aspectos morfológicos de Erysiphe em Mentha x villo$s a$. (A) Conidióforos e conídios vistos em microscopia de luz. (B) Conidióforo e conídios vistos em microscopia eletrônica de varredura. Detalhe dos apressórios no retângulo (Barra $=20 \mu \mathrm{m})$. $(\mathbf{C})$ Face inferior de folha de Mentha x villosa inoculada com Erysiphe, exibindo sinais do patógeno. 